\title{
Evaluation of the diesel engine feed by unified battlefield fuel F-34/F-35 mixed with biocomponents
}

The problem of the military vehicles engines fuelling increases with the growth of the amount of vehicles in the armies. At the same time, another problem with fuel supply in modern engines is the use of bio component additives, which changes characteristics (quality) of the used fuels. Therefore, it is important to take actions to adapt engines to powering with fuels coming from renewable sources.

The aim of the research was to evaluate the possibility of feeding the diesel engine (influence on the useful parameters and composition) with mixtures of the unified battlefield fuel F-34/F-35 with biocomponents in the form of anhydrous ethyl alcohol and RME. The tests were conducted during fuelling of the engine with six kinds of fuels: basic fuel (diesel oil), NATO code F-34/F-35 fuel, as well as fuel mixtures: F-34 and RME with different ratio and F-34/F-35 with bioethanol. In the result of the research it was concluded that the parameters of the G9T Renault engine with the common rail fuel system in terms of F-34 and RME consumption (using) decreased in comparison to diesel oil basic fuel. It is not possible to supply the engine with the mixture of ethyl alcohol and F-34 fuel-alcohol precipitation and obliteration of fuel system components

Key words: diesel engine, fuel supply system, F-34/F-35 fuel, Rapeseed Methyl Esters, bioethanol

\section{Introduction}

Liquid fuels are the most important source of energy on modern battlefield. Availability of fuels decides about mobility of the army, effectiveness of weapons or other support equipment and delivery of needed amount of supplies. Realisation of increasing requirements of fighting troops in fuels or lubrication oils is one of the most important problems of logistic supplying of a battlefield. It is calculated, that mean use of fuel and lubrication oil may reach $30 \mathrm{~kg}$ per one soldier per day $[4,11]$. The delivery of such a big quantity of supplies to the army, in terms of enemy interaction on communication systems and supplying infrastructure is an enormous sophisticated problem. It is why there is a trend to standardize all sorts of fuels in the army.. Fuels known as F-34/35 were introduced. It has the same base components as plane fuel JP8 (JET-A1). It's final quality is the effect of using additive components added to the base fuel before final distribution of fuel to a vehicle's tank.

Nowadays the F-34/35 fuel is taken as unified battlefield fuel for all diesel engines of NATO nations. At the end of 20th century the F-34 fuel was taken under investigation, which focused mainly about elder generation engines completed with in-line and rotation injection pumps [2], without engines with high pressure Common rail systems. From the time of introduction that fuel the injection equipment has changed. In-line injection pumps with plungers and barrels injection units are used very rarely. Common Rail and unit injection systems are used instead. In that system injection pressure reaches 140-200 MPa. It has a significant change on fuel quantity during injection $[7,8,10,11,12]$. Terms condition of fuel before injection to combustion chamber are changed relevantly, and temperature is much higher in comparison to classical in-line injection pump.

The Common Rail systems are commonly used in engines of cars, low duty and heavy duty trucks, locomotives and vessels as well as combat vehicles, for instance the MTU engines of MT 880 series. In these engines in-line pumps used in earlier version were replaced by CR sys- tems. Hat systems are widely used in heavy duty trucks, which are in possession of Polish Army (MAN, IVECO, SCANIA).

Using raw F-34 fuel to fuel engine equipped with Common Rail system may cause serious change of work parameters. Own investigation of the G9T engine equipped with CR fuelling system led in Military University of Technology $[10,11]$ shows important diminish of maximum torque and $\mathrm{NO}_{\mathrm{x}}$ in exhaust gases and increasing of specific fuel consumption.

The F-34/35 fuels in compare to diesel oil are characterised by better characteristic in low temperature, less viscosity, less cetan number, less heat value. Technical advantage of unified fuel is: compatibility to aircraft fuel (JET-A1), less sensibility on biological contamination, availability on airports all over the world, better lowtemperature characteristic, less possibility of flare/selfignition in comparison to wide fraction hydrocarbons fuels, less emission of toxic components. Logistic advantages are supplying only one sort of fuel in the whole army, simplification of supply chain and unification of storehouses and storing facilities.

Disadvantages of the unified fuel are increasing needs and demands for fuels based on kerosene and diminish of demands for other fuels. It may cause increasing of a fuel price, diminish of an engine power connected with less heat value of kerosene, needs for modernization of currently used equipment and using fuel additives.

Using of fuels which consist of renewable components such as rapeseed methyl esters (RME) may cause shortening of supply chains. The reason is using local source of a rapeseed from nearby grain elevators which are spread on over the country. The only demand is to introduce an installation for rapeseed oil pressing and for it esterification in the army. Then the vulnerability of the army for fluctuation of supply smoothness in case of a military conflict.

Fuels which consists of RME and bioethanol has a little bit different characteristics then hydrocarbons fuels. It depends on different composition, because in molecule struc- 
Table 1. Chosen characteristics of fuels used during investigation $[3,11,14,16]$

\begin{tabular}{|c|c|c|c|c|c|}
\hline Quantity & Unit & $\begin{array}{l}\text { military standard } \\
\text { diesel fuel IZ-40 }\end{array}$ & RME fuel & Bioethanol & F-34 fuel \\
\hline Density in temp. $15^{\circ} \mathrm{C}$ & $\mathrm{g} / \mathrm{cm}^{3}$ & 0.831 & 0.881 & 0.790 & 0.804 \\
\hline Heat value & $\mathrm{MJ} / \mathrm{kg}$ & 43.2 & 38.3 & 27.2 & 42.8 \\
\hline Temperature of ignition & ${ }^{\circ} \mathrm{C}$ & 66 & 177 & 12 & 57 \\
\hline Temp. of cold filter block & ${ }^{\circ} \mathrm{C}$ & -31 & -9 & & -54 \\
\hline Kinematic viscosity in $40^{\circ} \mathrm{C}$ & $\mathrm{mm}^{2} / \mathrm{s}$ & 2.35 & 4.60 & 0.90 & 1.27 \\
\hline Sulphur ratio & $\mathrm{mg} / \mathrm{kg}$ & 350 & 19 & - & 3000 \\
\hline Cetane number & - & 50 & 43 & 8 & 45 \\
\hline
\end{tabular}

ture apart from a carbon and a hydrogen there is a quite big dose of an oxygen (ca. 12\%). An oxygen ratio and unsaturated bindings conduced to auto ignition and complete combustion. An oxygen contained in fuel has more reactivity then an oxygen consisted in the air, it increase of a cetan number of that fuel. Changing of combustion process has positive influence concentration of toxic components and diminishes a smoke emission. Disadvantage of RME is large amount of water and aggressive influence on rubber parts and film-coating lacquer. $[6,9,12,15,16]$. That fuel has more density and viscosity, that its addition to standard F-34 fuel should cause the approach of the F-34 fuel attributes to diesel oil characteristic. The most important drawback of ethanol is low calorific value, low cetane number and high hygroscopicity. These features affect negatively the properties of petroleum-based fuel mixtures with bioethanol. These properties are significantly influenced by the injection of fuel into the combustion chamber, mixture formation and combustion process, which in turn affects the engine performance and the emission of toxic exhaust components.

\section{Aim and range of work}

Current fuel situation in the world and predicted diminishing of natural sources of oil compel to searching for new kinds of fuels. It concerns fuels used to feed of military vehicles as well. Despite that the F-34 fuel was taken by NATO nations as basic fuel, there is very seriously considered the situation that will force to renew this fuel with other, even bio products.

The aim of the research was the empirical assessment of the possibility of feeding the self-ignition engines (influence on the useful parameters and composition) with mixtures of the unified battlefield fuel F-34/ F-35 with biocomponents in the form of anhydrous ethyl alcohol and RME.

\section{Object, methodizes and range of investigation}

The object of investigation was a four cylinder Renault G9T diesel engine with $95 \mathrm{~kW}$ effective power with rotational speed $\mathrm{n}=2500 \mathrm{rpm}$ and $280 \mathrm{Nm}$ torque with rotational speed $n=1750 \mathrm{rpm}$, used in propulsion systems of light duty vehicles (LDV) of different producers. This is an engine with direct injection system equipped with a highpressure CR injection system. The engine is turbocharged and equipped with charged air-cooling system (intercooler).

The range of investigation consisted of the engine effective parameters, parameters of combustion process and composition of exhaust gases measure. The investigation was led for all the engine work field (speed characteristic and series of load characteristics in all range of rotational speed of the engine). The investigation of load characteris- tics was led as a method of passive experiment in steady state of the engine work. The external speed characteristic was done as well in range of 1000-3750 rpm with $250 \mathrm{rpm}$ step.

During investigation effective parameters of the engine, temperature (cooling liquid, lubrication oil, exhaust gases before and after turbocharger), concentration of: carbon dioxide, oxygen, carbon monoxide, hydrocarbons, nitrogen oxides, and smoke measured as extinction of radiation absorbed by exhaust gases. Due to the volume of collected research material, article presents only the results obtained during engine operation on external characteristics.

Results of engine parameters measuring were gathered during all experiment. The purpose was current observation of a technical state or reveal of the engine possible malfunction circumstances and observation of next steps of investigation. The results of the engine effective parameters measuring were calculated back to normal atmospheric condition according to PN-ISO 15550:2009 standard.

During the investigation the engine was fuelled with fuels:

- military standard diesel fuel - in the paper it is signed as $\mathrm{SDF}$,

- F-34/F-35 fuel - in the paper it is signed as F-34,

- mixtures of the F-34/35 fuel and RME - in the paper it is signed as B-20, B-40, B-60 and B-80 where the number following letter $B$ stands for a weight ratio of RME in the mixture.

- mixtures of the F-34/35 fuel and bioethanol - in the paper it is signed as E-5, E-10, where the number following letter $\mathrm{E}$ stands for a weight ratio of bioethanol in the mixture.

\section{Results of investigation}

The analysis of investigation results lets to evaluate the different kinds of fuels influence on the engine effective parameters, indicated parameters, concentration of toxic components and smoke in exhaust gases.

Based on the analysis of measured external characteristics of the G9T engine fuelled with different kind of fuels it must be said, that the biggest effective power of the engine is reached when it is fuelled with basic fuel (SDF) -Fig. 1a and $1 \mathrm{~b}$. The Usage of the F-34 fuel caused a little diminish of effective power $(\mathrm{Ne})$ ca. (1-2)\% . The RME or bioethanol addition to the F-34 fuel caused next diminish of effective power ca. (7-8)\%, depending on F-34/RME mixture ratio (Fig 1b). The reason of it is increasing of F-34/RME mixture density and diminishing of a heat value. Differences in effective power increase due to rotated speed of the engine. 
a)

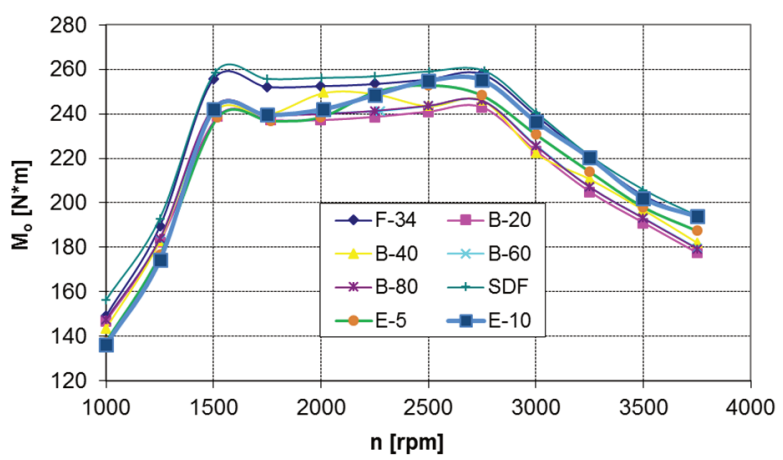

c)

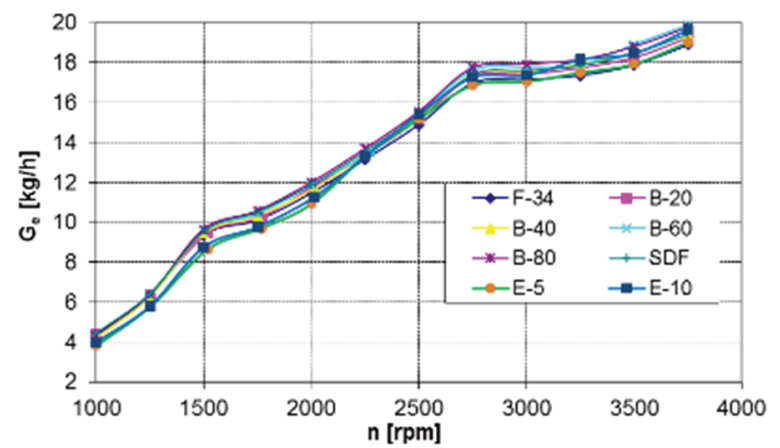

b)

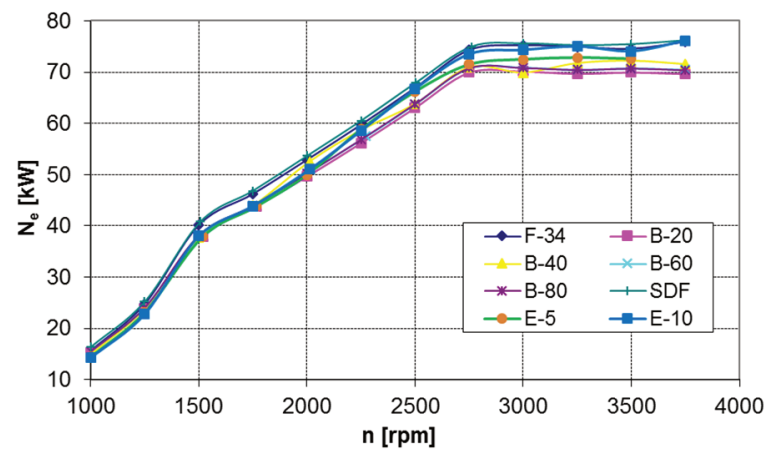

d)

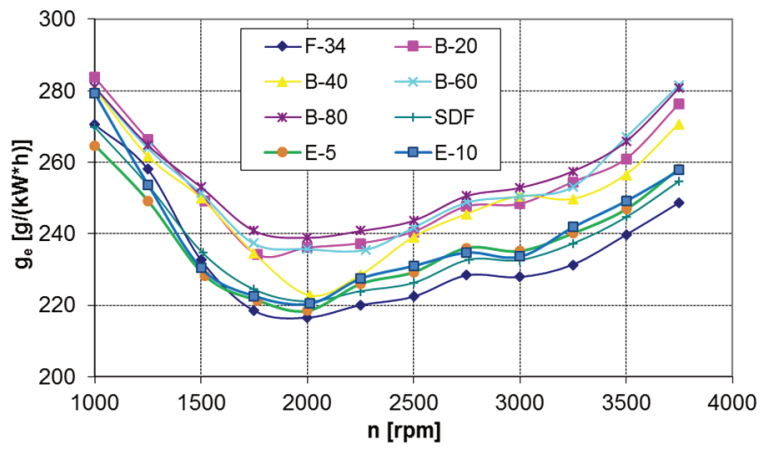

Fig. 1. External characteristic of the engine: a) torque, b) effective power, c) fuel consumption, d) specific fuel consumption

The least fuel consumption is reached for diesel oil (Fig. 1c), which is the basic fuel, although values for F-34 fuel are very similar. Using RME in fuel mixtures caused increasing of fuel consumption $(\mathrm{Ge}) \mathrm{ca}$. (3-5)\% depending on F-34/RME ratio and rotated speed of the engine. The addition of bioethanol caused a drop in hourly fuel consumption (Ge) by about (6-8)\%. depending on the concentration of bioethanol.

It is caused by lesser heat value of the mixture and necessity of delivering more fuel to the cylinder to reach the same effective power. In order to eliminate such impaired phenomena, it is necessary to modify the controller software in order to optimize the time and injection angle to a specific fuel mixture.

The least specific fuel consumption value was observed for the F-34 fuel (similar values for SDF) - Fig. 1d, 2d, which are $233 \mathrm{~g} /(\mathrm{kW} \cdot \mathrm{h})$ and $236 \mathrm{~g} /(\mathrm{kW} \cdot \mathrm{h})$ respectively with rotational speed $\mathrm{n}=1500 \mathrm{rpm}$. Higher specific fuel consumption is caused by smaller heat value and bigger viscosity of RME. Bigger viscosity influenced on worse spraying and bigger heterogeneity of fuel stream. It caused incomplete combustion of air/fuel mixture. Changing the viscosity of fuel in order to the optimized results for engine control system was programmed, cause change injectors opening time, which negatively affects the process of creating a combustible mixture and its combustion.

The positive effect of F-34/RME mixtures' influence on emission of smoke was observed - Fig. 2f, 3a. The biggest amount of smoke was observed when the engine was fuelled with F-34 (similar values was for SDF), although with mixtures with of increased ratio of esters smoke is almost 2...3 times lesser for B-100. This trend is observed in whole range of the engine rotational speed. A littlelater beginning of injection caused strong growth of smoke emission when the engine is fuelled with diesel oil. Diminish of smoke emission is caused by lesser effective power as well. Impaired effect of F-34 fuel mixtures with bioethanol on the smokiness of fumes was observed - Fig. 2f, 3a. Increased, almost 5 times, in smoke opacity was noted for rotational speeds above $n=2500 \mathrm{rpm}$, which indicates the adverse impact of bioethanol on the process of feeding and burning. These changes are accompanied by an increase in the exhaust gas temperature.

Temperature of exhaust gases on outlet tube is the highest when the engine is fuelled with SDF and reaches $620^{\circ} \mathrm{C}$ with $n=1500 \mathrm{rpm}-$ Fig. $3 \mathrm{~b}$. The lowest temperature ca. $592^{\circ} \mathrm{C}$ of exhaust gases was observed with mixture B-80 with $\mathrm{n}=1500 \mathrm{rpm}$, it can be observed diminish of temperature of more than $45^{\circ} \mathrm{C}$. There is observed that with increasing RME ratio in fuel mixture temperature of exhaust is lower. The addition of bio-ethanol to the F-34 fuel caused a significant increase of the exhaust gas temperature above the speed $\mathrm{n}=2500 \mathrm{rpm}$, by about $(20-30)^{\circ} \mathrm{C}$, depending on the rotational speed. This is related to the extension of the self-ignition delay period and the shift of part of the combustion process to the exhaust stroke. This is a very unfavourable phenomenon due to the decrease in the efficiency of the engine and the possibility of thermal overloading of engine components - specifically turbochargers.

While rotational speed is low big concentration of carbon monoxide is observed. Increasing speed causes significant diminish of carbon monoxide concentration. The biggest concentration is observed during fuelling the engine with F-34. Mixture with RME caused diminish of its concentration in range of high speed of the engine ca. (10$15) \%$-Fig. 4a. Lower concentration of carbon monoxide in 
a)

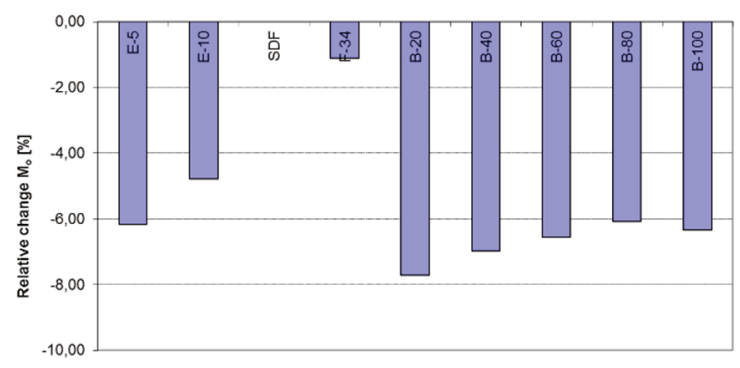

c)

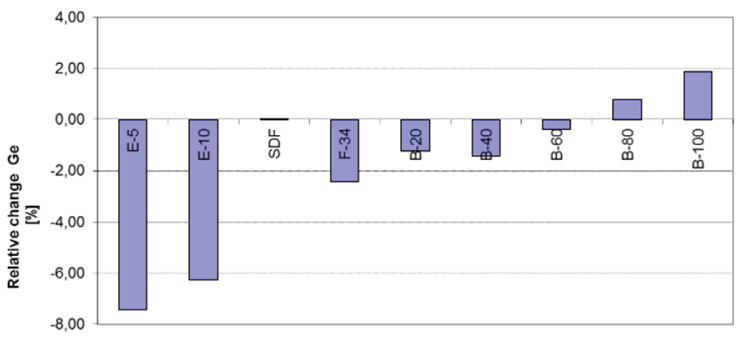

e)

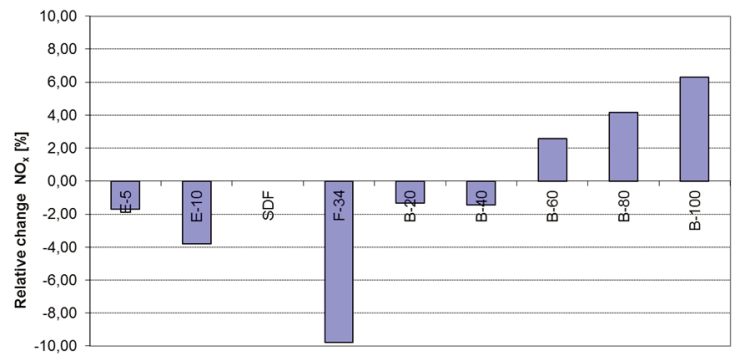

b)

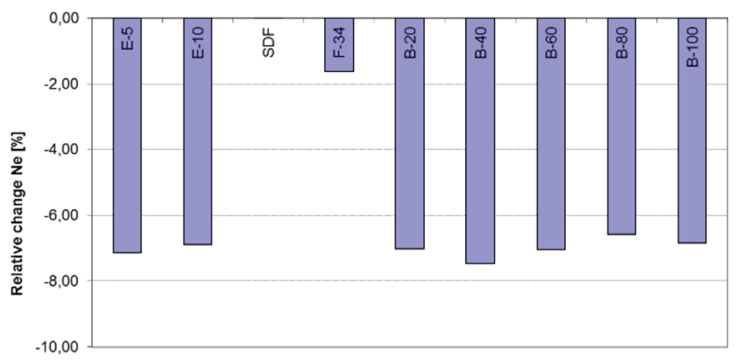

d)

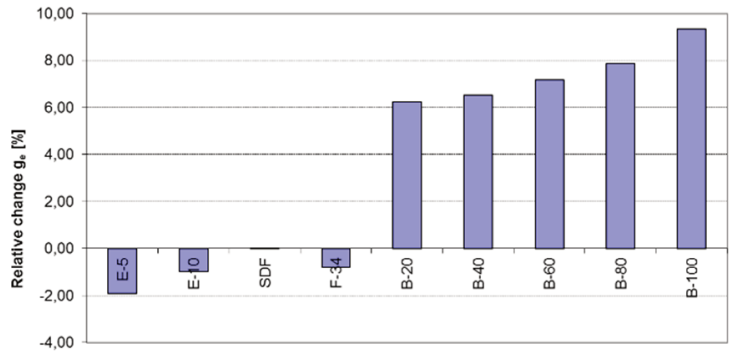

f)

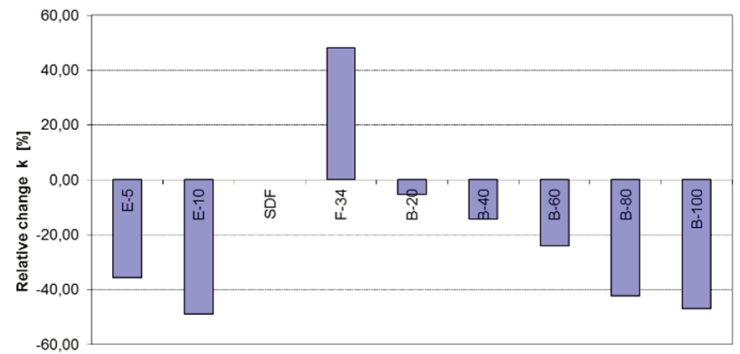

Fig. 2. Relative changes in engine operating parameters for maximum torque - $1500 \mathrm{rpm}$ : a) torque, b) effective power, c) fuel consumption, d) specific fuel, e) concentration of nitrogen oxides in exhaust, f) extinction coefficient of absorbed radiation

a)

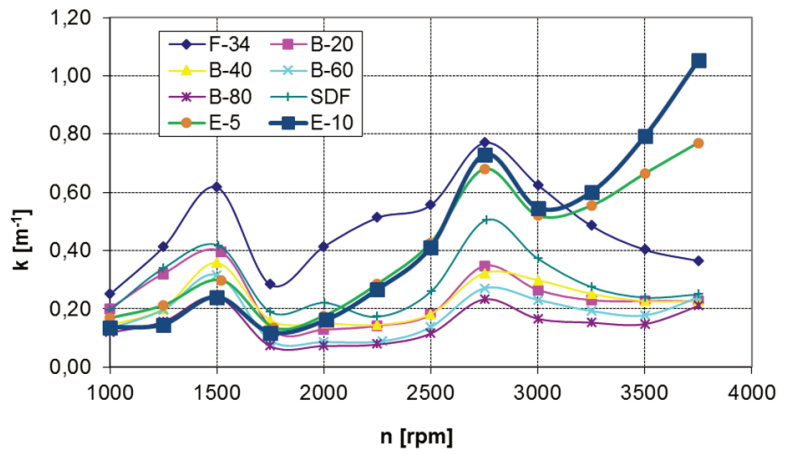

c)

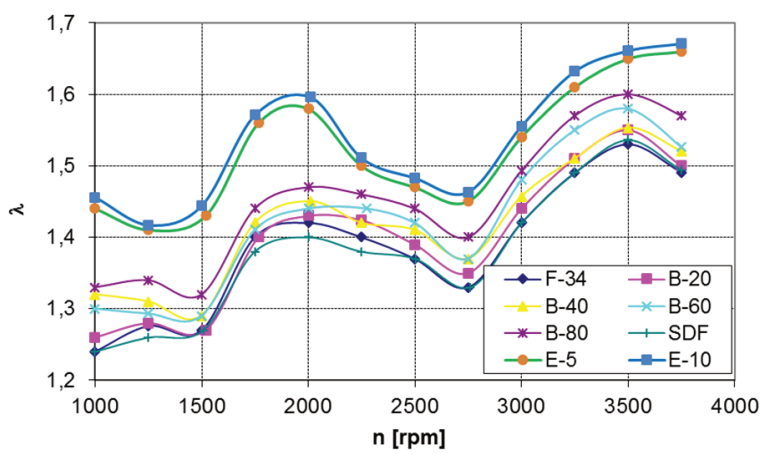

b)

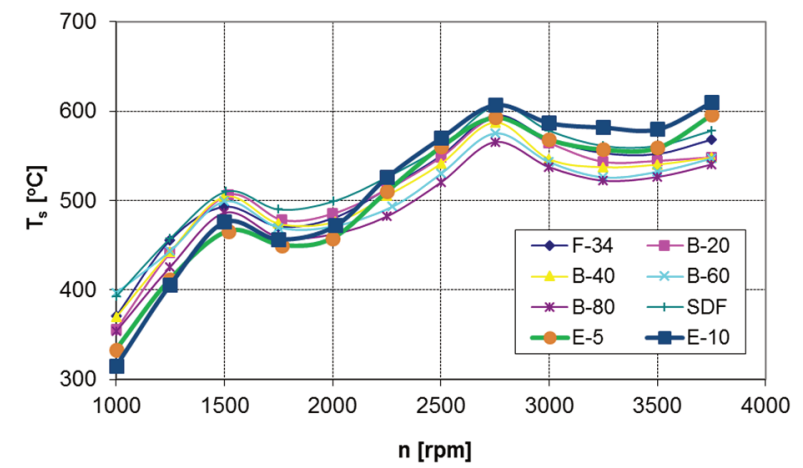

d)

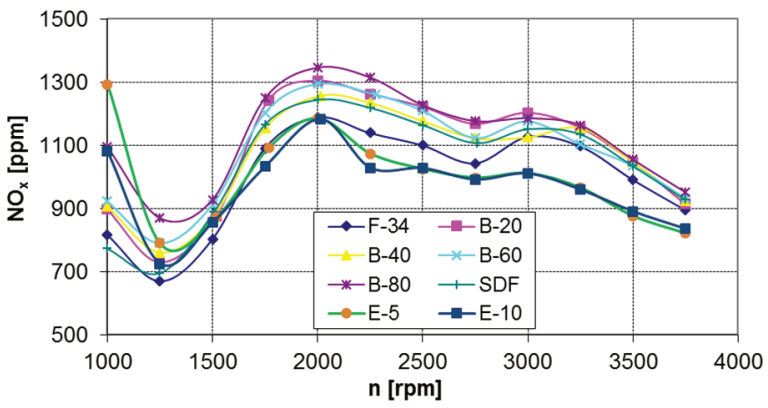

Fig. 3. External characteristic of the engine: a) extinction coefficient of absorbed radiation , b) temperature of exhaust gases, c) air/fuel ratio coefficient, d) concentration of nitrogen oxides in exhaust 
a)

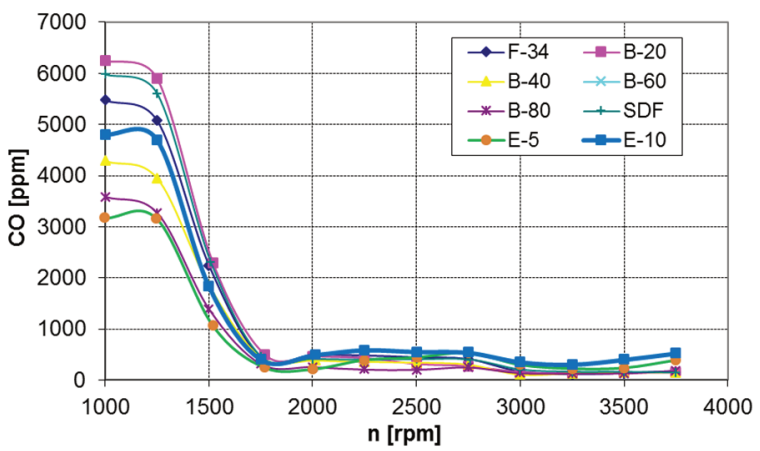

c)

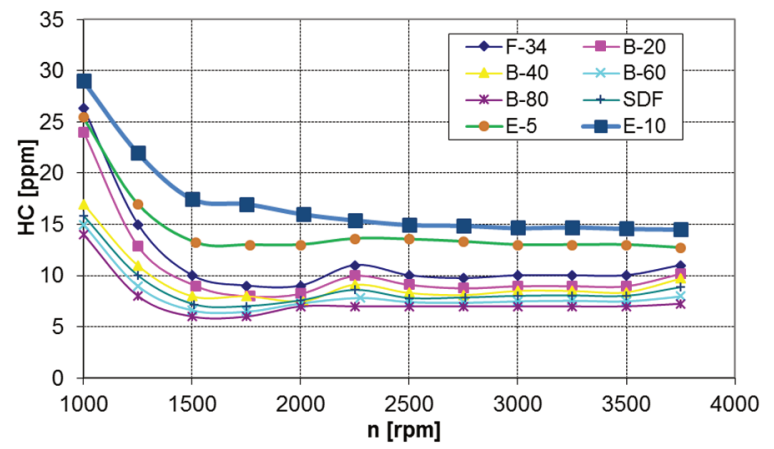

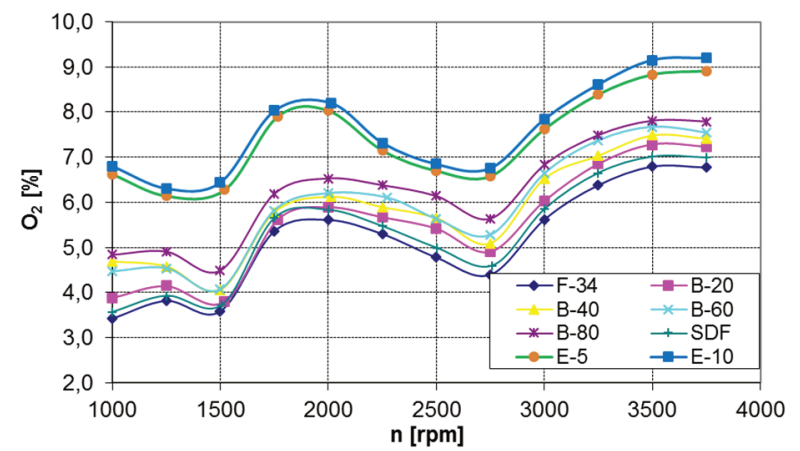

d)

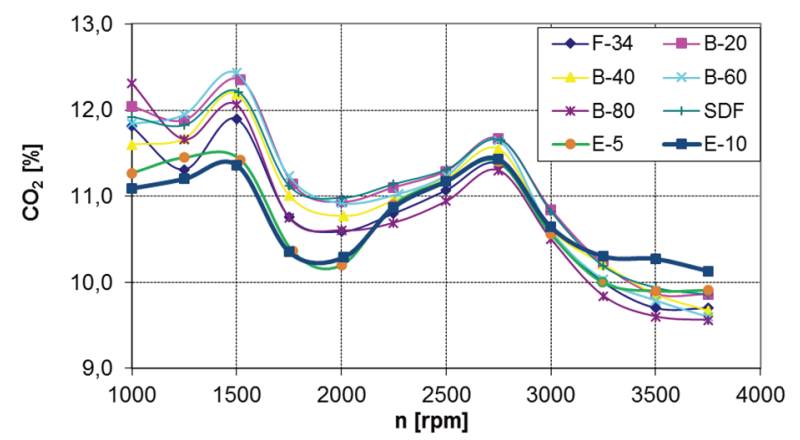

Fig. 4. External characteristic of the engine: a) concentration of carbon monoxide in exhaust, b) concentration of oxygen in exhaust, c) concentration of hydrocarbons in exhaust, d) concentration of carbon dioxide in exhaust

exhaust during fuelling of the engine with F-34/RME mixture testifies about changing of combustion process in compare to pure F-34 and SDF. RME additives positively influenced on carbon monoxide concentration in range of low speed of the engine. When rotational speed is above 1500 $\mathrm{rpm}$ it is on the same level, without regard on used kind of fuel.

The lowest value is seen during fuelling with F-34 and SDF. The biggest during fuelling with B-80 - increasing reach ca. $(20-25) \%$ - Fig. 4 b.

Concentration of hydrocarbons in exhaust gases is about $50 \%$ lower when fuelling with B-80 mixture for all range of the engine speed (Fig. 4c). Lower concentration of hydrocarbons in exhaust is a result of higher concentration of oxygen in air/fuel mixture as it was in case of carbon monoxide.. Concentration of carbon dioxide is opposite to oxygen concentration. The lowest value is observed for F-34

a)

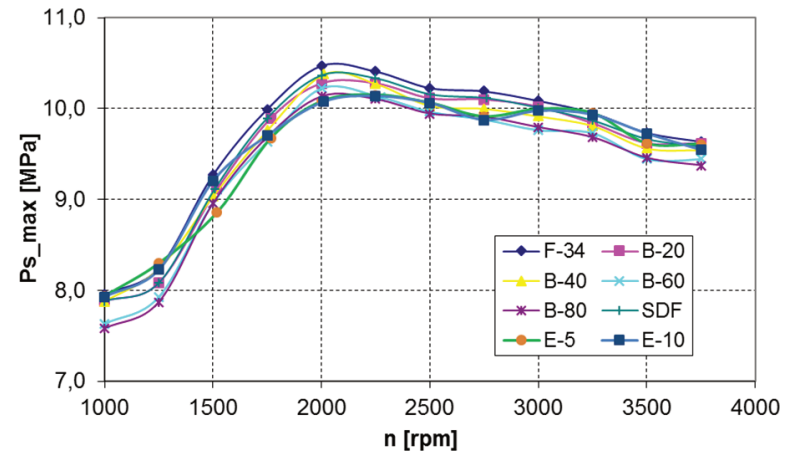

fuel and the highest (ca. (6-10)\% for F-34/RME mixtures Fig. 4d).

\subsection{Influence of F-34 and RME mixture on working parameters of the engine}

Analysis of combustion process in the G9T engine combustion chamber was carried on the basis of the engine working cycles investigation. During investigation several dozen of combustion processes cycles were saved, and next 10 of them were statistically recalculated and characteristic parameters of combustion process were found. the maximum value of pressure and angle of auto-ignition delay are shown on graphs. The angle of auto-ignition delay is appointed as a difference between start of an injector needle lift and start of an active combustion in the engine chamber, which was determined based on the change in the derivative of the pressure course in the engine's combustion chamber

b)

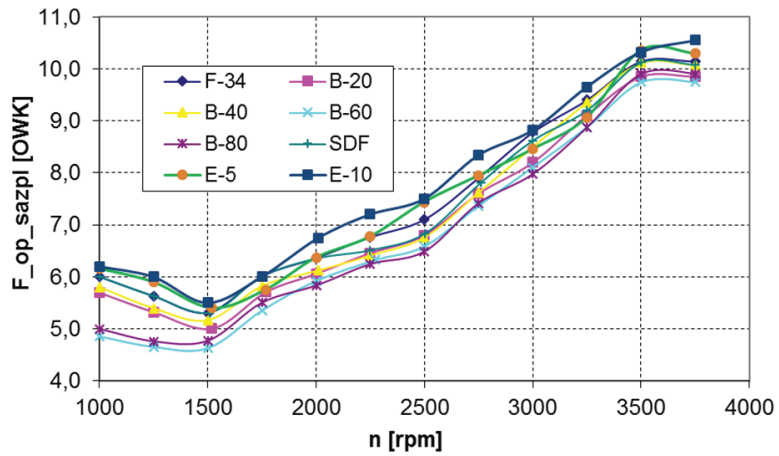

Fig. 5. External characteristic of the engine: a) maximum combustion pressure, b) angle of auto-ignition delay 
Significant differences are seen on line of maximum pressure in the combustion chamber. The highest values of pressure were measured on F-34 and SDF fuels. This values are similar but a little bit higher in case of F-34 fuelling. This differences are no higher than $0.1 \mathrm{MPa}$ (Fig. 5a). When mass ratio of RME increasing in a fuel mixture the diminish of maximum pressure value in the chamber is observed. The lowest values were observed for B80 mixture. Differences between maximum value for F-34 and SDF fuels and minimum value for B80 mixture were ca. 0.4 $\mathrm{MPa}$ in almost all range of rotational speed of the engine. The reason of such high decrease of pressure value is the lower dose of energy (lower heat value of fuel mixtures) consisted in fuel dose injected to the combustion chamber as well as longer time of injection. It causes slower heat transfer and diminish of peak values of combustion pressure.The addition of bioethanol in the F-34 fuel increases the maximum pressure in the combustion chamber. This is related to the increase of the self-ignition delay angle (decrease in the number of cetane mixture). This phenomenon is disadvantageous due to the increase of mechanical loads of the crank-crank system and the probable increase of noise emission.

After analysing the influence of RME ratio in F-34 fuel on the angle of auto-ignition delay (Fig. 5b) it is seen, that increasing of RME ratio causes shortening of angle of autoignition delay. The lowest values of angle of auto-ignition delay were observed for B80 mixture, and the highest were for F-34 fuel. For rotational speed $n=1000 \mathrm{rpm}$ difference is ca. $1^{\circ}$ of crank shaft rotation (CSR) and it decreases with the increase of rotational speed. For speed $n=3500 \mathrm{rpm}$ is equal $0.2^{\circ} \mathrm{CSR}$. Shortening of angle of auto-ignition delay for B80 fuel mixture is caused by lower temperature of auto-ignition as well as oxygen ratio in RME, which influence on speeding up of fuel oxidation. Observing the influence of the bioethanol content in F-34 fuel on the ignition delay angle (Fig. 5b), it can be noticed that the increase of bioethanol content causes a significant extension of the auto-ignition delay angle by about $1^{\circ} \mathrm{CSR}$, which is the result of a very small number of cetane bioethanol.

\section{Conclusion}

The usage of unconventional fuels for fuelling of military vehicle engines nowadays is a wide disputed problem. The numerous investigations about adaptation of renewable fuels for fuelling of diesel engines are lead. The best matches for fuelling diesel engines are methyl esters of fatty acids. In Poland they are acquired with processing of rapeseed oil (RME).

As the result of investigation it was ascertained that the G9T Renault engine parameters equipped with the Common Rail system fuelled with F-34/biocomponent mixtures changed in comparison to standard F-34 or DF fuels. It is possible to power the engine with the high-pressure common rail supply system with the aviation fuel mixtures F34/F-35 and RME

On the basis of the research it is to be said that:

- the diminish of the engine effective power reaches $15 \%$ (depending of the engine work condition or used fuel mixture), during fuelling with F-34/RME mixtures,

- in comparison to F-34 and DF fuels, lower effective power of the engine is connected with lower heat value of RME,

- specific fuel consumption is $15 \%$ higher for F-34/RME mixtures especially in ranges of high speed and load of the engine,

- using RME as additives for F-34 fuel causes the diminish of carbon monoxide concentration up to $15 \%$ especially in range of low values of rotational speed and load of the engine,

- increasing of oxygen ratio in exhaust gases of ca. $25 \%$ is caused by presence of oxygen in RME molecule,

- hydrocarbons concentration in exhaust gases is lower up to $50 \%$ during fuelling the engine F-34/RME mixture.

- The addition of bioethanol adversely affects the engine's operating parameters - smoke and exhaust gas temperature increase. Several hours of engine operation on the E-10 mixture led to damage to the power system - obstruction of one section of the high-pressure pump and the injector.

The investigation about unconventional fuels application contributes to its introduction to mass production. Leading that investigation is crucial because it lets us to evaluate the influence of fuel composition on engine's work in different load and speed condition. The next stages of the researches will be based on the influence of the ternary mixtures (F-34 fuel, RME and bioethanol) on the performances of the diesel engine with Common Rail.

\section{Nomenclature}

CSR crank shaft rotation

RME Rapeseed Methyl Esters

DI direct injection

SDF military standard diesel fuel

\section{Bibliography}

[1] AMBROZIK, A., KRUCZYŃSKI, S., JAKUBIEC, J., ORLIŃSKI, S. Wpływ zasilania silnika spalinowego o zapłonie samoczynnym paliwem mineralnym i roślinnym na proces wtrysku oraz rozpad strugi paliwa. Journal of KONES Powertrain and Transport. 2006, 3(13), 21-28.

[2] BACZEWSKI, K., KAŁDOŃSKI, T., WALENTYNOWICZ, J. Sprawozdanie z realizacji pracy naukowobadawczej. Opracowanie koncepcji wdrożenia jednolitego paliwa do lotniczych silników turbinowych i silników wyso-

koprężnych. Wojskowa Akademia Techniczna, Warszawa 2001.

[3] BACZEWSKI, K., KAŁDOŃSKI, T. Paliwa do silników o zapłonie samoczynnym. WKE. Warszawa 2004.

[4] BRZOZOWSKI, K., NOWAKOWSKI, J. Toxicity of exhaust gases of compression ignition engine under conditions of variable load for different values of engine control parameters. Eksploatacja i Niezawodnosc-Maintenance and Reliability. 2011, 4(52), 56-62. 
[5] CHONG, CH.T., HOCHGREB, S. Spray flame structure of rapeseed biodiesel and Jet-A1 fuel. Fuel. 2014, 115, 551558.

[6] DAISUKE, K., HAJIME, I., YUICHI, G. et al. Application of biodiesel fuel to modern diesel engine. SAE Technical Paper. 2006, 2006-01-0233.

[7] DAGAUT, P., GAÏL, S. Chemical kinetic study of the effect of a biofuel additive on Jet-A1 combustion. Journal of Physical Chemistry A. 2007, 111(19), 3992-4000.

[8] HILEMAN, J.I., DONOHOO PEARL, E., STRATTON, R.W. Energy content and alternative jet fuel viability. Journal of Propulsion and Power. 2010, 26(6), 1184-1196.

[9] HORN, U., EGNELL, R., JOHANSSON, B., ANDERSSON, O. Detailed heat release analyses with regard to combustion of RME and oxygenated fuels in an HSDI diesel engine. SAE Technical Paper. 2007, 2007-01-0627.

[10] KARCZEWSKI, M., SZCZECH, L. Influence of the F-34 unified battlefield fuel with bio components on usable parameters of the IC engine. Maintenance and Reliability. 2016, 18(3), 358-366. DOI: 10.17531/ein.2016.3.6

[11] KARCZEWSKI, M., WALENTYNOWICZ, J., SZCZECH, L. et al. Sprawozdanie $\mathrm{z}$ realizacji pracy naukowobadawczej. Określenie wpływu jednolitego paliwa F34/35 z biokomponentami na pracę wysokociśnieniowego układu zasilania typu „Common Rail”. Wojskowa Akademia Techniczna. Warszawa 2010.

[12] MAYER, A., CZERWIŃSKI, J., WYSER, M. et al. Impact of RME/diesel blends on particle formation, particle filtration and PAH emissions. SAE Technical Paper. 2005, 200501-1728.

[13] SZLACHTA, Z. Zasilanie silników wysokoprężnych paliwami rzepakowymi. WKE. Warszawa 2002.

[14] PAŁUCHOWSKA, M., DANEK, B. Specyfikacje jakościowe bioetanolu i biopaliw do silników o zapłonie iskrowym. NAFTA-GAZ. 2009, 2.

[15] SZABADOSA, G., BERECZKYB, A., AJTAIC, T., BOZÓKIC, Y. Evaluation analysis of particulate relevant emission of a diesel engine running on fossil diesel and different biofuels. Energy. 2018, 161, DOI: 10.1016/ j.energy.2018.07.154

[16] SZABADOSA, G., BERECZKYB, A. Experimental investigation of physicochemical properties of diesel, biodiesel and TBK-biodiesel fuels and combustion and emission analysis in CI internal combustion engine. Renewable Energy. 2018, 121. DOI: 10.1016/j.renene.2018.01.048

\begin{abstract}
Mirosław Karczewski, DEng. - Faculty of Mechanical Engineering, Military Academy of Technology.

e-mail: miroslaw.karczewski@wat.edu.pl
\end{abstract}

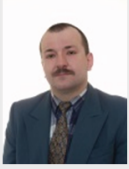

